\title{
Dearth of Spirituality in the Protagonists of the Select Novels of Upamanyu Chatterjee
}

\author{
P. Rajitha ${ }^{1 *}$, G. Damodar ${ }^{2}$ \\ ${ }^{1}$ Research Scholar, Department of English, Telangana University, Nizamabad, India \\ ${ }^{2}$ Professor, Department of English, Chaitanya University, Hanamkonda, India \\ *Corresponding author: pazhavara.rajitha@gmail.com
}

\begin{abstract}
This study examines the spiritual and ethical fall of man in English, August: An Indian Story, The Last Burden, and Weight Loss of Upamanyu Chatterjee. It aims at the modern man's shallow mindedness, his meagre understanding of life, vague expression of achievement and success. The protagonists of the novels, Agastya or August, Jamun and Bhola's plight and turbulence as modern men in terms of lack of spirituality and morals and principles is the focus of the novels. They are the definition of success for the society or for the people around them in today's rat race. They are the main focus of the novel. August's weakness about addiction to life killing drugs, women and wavering about having a family and spiritual strength, Jamun's commitment phobia and Bhola's perversion are portrayed brilliantly by Chatterjee. Chatterjee's heroes represent the Indian youth who are alienated from their own culture and roots. The psychological, cultural, political impact on the young generation and the dilemma of the people who were unable to come out of colonial rule mentally, are the major expressions of this novel. They are half Indian and half western, rootless and frustrated.
\end{abstract}

Keywords: Colonialists, Contemporary, Fictional, Postmodern, Self-realization, Spirituality.

\section{Introduction}

Upamanyu Chatterjee has carved a separate niche for himself on the vista of contemporary Indian English literature, as the master of grotesque,' the witty biographer of the misfit.' (Prasannarajan). His novels pine away with a view to all sorts of grotesques, within and outside, implicit in today's social and psychological, family and structural circumstances.

Upamanyu Chatterjee is a social realist whose artistic endeavour shapes what can be called the foundation, the allembracing, theme of identity and its plight in a hostile ambience. It covers many angles or issues and is the dominant aspect of his novels. English August: An Indian Story (1988), The Last Burden (1993) The Welfare State Mammaries (2000) Weight Loss project protagonist's rootlessness. The portrayal of the protagonists and other characters is the common factor which connects all the novels.

Spirituality has been considered to be a driving force for everyone since time immemorial as it guides people to follow good and not evil. Lack of spirituality devastates and degenerate's human mind. This is so contagious that it spreads to others and makes them feel restless. This waywardness of mind results in the downfall of man.

In Paradise Lost, Adam's downfall starts when he defies God's order, like August disregards his own culture, tradition and culture for the sake of another culture about which he knows nothing. He is fascinated by the outer beauty of it, ignoring the inner beauty and inner voice of his culture. This is evident when August, in his loneliness, masturbates, takes drugs as he thinks that this is the only way to overcome his dull life in Madna as a recluse. Though, surrendering oneself to God Almighty is pious act, helping the poor and the downtrodden are also a part of every human's life.

Adam's fall is due to his love for Eve and not out of ignorance. The fall of protagonist in English, August is due to his obsession for something which is really alien to him and for the craze for new things, like western culture and English language which he thinks will give him an edge over others and puts him in a superior place in the society. Unfortunately, August is a misguided youth of modern India who yearns for immediate happiness and success by taking drugs.

These materialistic things make him lead his life mechanically and disinterestedly. Chatterjee attacks the selfserving and irresponsible attitude of youth of modern society, and the anxiety, depression which they undergo and fall prey to drugs and alcoholism. This disorientation is due to lack of spiritual bliss in which the present day youth resist to take shelter.

'Lust' is one of the themes of The Waste Land especially in the poem, The Fire Sermon, Eliot describes a scene of a young sailor who will have sex with a typist and she reciprocates disinterestedly. This shows sexuality of Eliot's time. This is applicable to modern day youth. August will have sex with Daya without any love or affection but to satisfy his sexual desire in English, August. This is the similarity between these two novels regarding 'lust' and the result is degradation of human values and principles which are shocking to everyone. Eliot talks about barrenness of love between the couple. Chatterjee also discusses this concept in some of his other novels too. His protagonists, August looks for women and thinks of women in his leisure time. His mind is filled with women when he is leading a lonely life in Madna. Bhola in Chatterjee's Weight Loss is a sexual pervert and bisexual who 
is ready to have sex with Titli and her husband, the other character is Jamun in The Last Burden will have extra marital affair with Kasthuri even after she gets married. Eliot says sexuality is without "life" and "purpose" and had changed for sexual fulfillment. Chatterjee probes into this and expresses that sexuality is no more a concept of bonding people with love, and it is only meant to satiate carnal desires of people. This is very dangerous as it destroys the basic foundation of institution of marriage and family. In this chaotic and turbulent situations also, Eliot's poem ends with a sacred chant, "Datta. Dayadhvam. Damyata.? Shantih shantih shantih" (WL 433444). This conveys the peace inherent in its inner sound. Let peace prevail everywhere. This gives hope to the coming generation. August also enlightens himself by meeting the father and son duo who run a charity home selflessly. This can be called self-realization by August.

Spirituality and religion are different from each other, but in the $21^{\text {st }}$ century, these two are inseparable and people misunderstand these two as one. Spirituality is everlasting and eternal whereas religion is man-made. Spirituality gives peace of mind to all humans irrespective of his or her religion. Religion is considered to be faith in a concept or dogma and has raised barriers among the people. Religion divides people whereas spirituality unites the human race. Religion has its own positive side too. If the approach of humans towards religion is good, then it will make him/her a super human with super qualities and makes that human a well-balanced person and if the approach is bad, it will make the person a religious fanatic. Every human has God and evil within him/her. It is in one's own mind to discover oneself. August lacks faith in spiritual knowledge and spiritual discovery. This causes restlessness and despair in his life and his life becomes directionless quite for some time. The self-discovery of August takes place only if he keeps himself away from all those things which he considers close to his heart. This only can emancipate August from all his sins. He is caged by these evils due to lack of guidance and spiritual preaching.

Spirituality is a worldwide phenomenon and it is a general idea inferred or derived from specific instances. Humans surrender themselves to an all pervading and guiding force who is omnipotent, omnipresent and omniscient and usually called God. Belief in God strengthens belief in ourselves. A person with spirituality wins the hearts of people, can deal with problems ease. He acquires peace, happiness, uprightness, tolerance and will be compassionate. He will not lack morals. In English, August, August receives two books, one is Bhagavadgita and the other one is Marcus Aurelius. Whenever he feels frustrated, he takes shelter in these books by reading them, which give him solace, yet he is unable to overcome his weaknesses. He is surrounded by the evils, such as immorality, unethical behaviour and addiction to drugs. His struggle to defeat these evils and taking the right path is guided by these books. This takes him to the common man and makes him understand the problems of poor and downtrodden. He partly survives from being totally damaged by evils surrounded.

The aspect of alienation that we see in Chatterjee's novels is fundamental to the colonial disruption of the urban Indian educated identity in terms of multiple divisions. There are distinctions between man and his conventional moorage between man and his kin, between man and his world; and, finally, there is a divide between man and his inner being. In his novels, Chatterjee is profoundly concerned with the implications of the encounter between the colonial influence of Britain and Indian society.

The notion of anti-hero as expressed in the main characters of the novels of Upamanyu Chatterjee rests on this divorce from the various segments of society and its institutions of the urban educated man. The exhaustion and breakdown of the force behind inspiring ideas and philosophies is the most destructive and thus most potent factor in generating fertility for the development of anti-heroic denizens of society.

These have been collectively referred to as 'great narratives' or 'meta narratives' in post-modernist terminology. Upamanyu Chatterjee's fictional world is a postmodern world characterized by the obvious signs of the breakdown of the great narratives of Indian values and the focus is on the consumerist way of life. In the context of Upamanyu Chatterjee, it is noteworthy that the post-modernity we experience in his novels is merely a sociocultural situation that traps his heroes, not intellectuals. The Unambiguous message from Upamanyu Chatterjee's novels is that in Indian culture, heroes such as Agastya Sen, Jamun and their lesser varieties are bound to appear, as is the case with global cultural dynamics.

In the field of Indian novels in English, Upamanyu Chatterjee has emerged as one of the most persuasive new voices. English, August: An Indian story is a fascinating metaphor for the failed search for self-realization of contemporary English educated Indian urban youth. In English, August: An Indian Story, Agastya Sen is a victim of the bureaucratic structure he comes to join. He lacks spiritual and moral strength.

Agastya Sen, the antihero, represents his time i.e. the last quarter of Indian urban life at various levels of the twentieth century. In this novel, Upamanyu Chatterjee focuses on the fact that urban Indians like August are victims of an alien cultural discourse that has been internalized by them in the course of their educational cultural nurturing. Upamanyu Chatterjee's core opinion is that the careerist English educated urban Indian youth experiences alienation from his origins at his deeper psychic level and is doomed to a life of unhappiness and boredom.

We see the hero in the novel The Last Burden (1993) as attempting to shed the 'burden' of family bonds, the personal realm of family relationships becoming the terrain of his action. The Last Burden's protagonist, Jamun, represents the average Indian growing up in an Indian metropolitan cities and always feeling that in New York or London he'll be more at home than in a tiny place in India. The novel's antiheroic protagonist is born into a hate-filled family. Chatterjee's social realism 
focuses on the issue of partnership in an ordinary middle-class household, exploring the state of mind of the anti-heroic Indian personality. After an intense textual study, the impression we can get is that the family relationship itself tends to be in the novel The Last Burden is chaotic, troublesome and full of disagreements. Jamun lacks ethics and faith in God. This lack of spirituality makes him a confused Indian youth.

Weight Loss focuses on the life of the disturbed, morally crippled, part fantasy part chaotic and complete abnormal protagonist Bhola. He shares the characteristics with previous Upamanyu Chatterjee heroes in general. Chatterjee's heroes are the results of India's hybridized and corrupted metro society. In Chatterjee's fictional world, Bhola is smart, obese and also womanish in physical appearance. He is good at academics, literature and language. He is sensitive to his setting, and as unsure and hesitant as the other protagonists of Upamanyu Chatterjee. The thing that makes him stand out is his much more extreme sexual inclination, so much so that it becomes both the central point of his life and the book. His sexual urge is his disease and his only relentless desire in life is to satisfy it. He works tenaciously and very effectively, on his weight loss program, which entails losing physical, mental and emotional 'weights' of all kinds. Therefore, throughout his life, he remains constantly concerned with two things: running and sex, which remain part of his weight loss program. They offer him a channel for his intense passions and allow him 'to lessen the load of the lumber in his head' (Chatterjee 33).

In the perverted life of Bhola, sex is the guiding and deciding force and his behaviour towards individuals around him relies on their sexual reciprocity. Sex is a wantonness for him from the very beginning of his life that makes him associate with anyone and everyone from teachers to landlady to roadside sadhus to servants in all kinds of bizarre decadence.

He experiences newer feelings, so far unknown to him, gazing at his daughter with tenderness and affection. His degenerate history catches up, though all his efforts at redemption are thwarted largely due to his own weakness in character. The tiny but precious moments of happiness and recovery are short-lived, leaving Bhola even more miserable and wrecked, going down the drain. The apogee of his gloomy and pathetic life arrives in the form of suicide that offers final and much sought salvation to him.
His death and a lot of young people's death is on the conscience of our society and nation. We have no time to understand the struggle, the pressure and the dejection faced by the young generation. It's a fact that young people are wayward due to apathy of the society. We are blind to the underlying crisis developing in the society. Everybody is too busy to notice this. Mental health awareness is the need of the hour. Everybody should provide some time for meditation and introspection. It's very important like exercise to body we should take full care towards mental health by listening to spiritual discourse. We need to proactively try to calm the mind through various means otherwise it will not be fit enough to face strains of life.

These problems are discussed in the novels of Upamanyu Chatterjee through his protagonists. His protagonists are intelligent but they really need empathetic mental wellness experts, very supportive social set up, like parents or family or friends. This is clearly portrayed through the characters, Agastya, Jamun and Bhola.

\section{Conclusion}

This paper presented an overview on dearth of spirituality in the protagonists of the select novels of Upamanyu Chatterjee.

\section{References}

[1] Brooks, Cleanth. "Irony as a Principle of Structure." Critical Theory Since Plato. Ed. Hazard Adams. New York: Harcourt Brace Jovanovich Inc., 1971

[2] Chatterjee, Upamanyu. Weight Loss. New Delhi: Vikings-Penguin Books (India), 2006.

[3] Hutcheon, Linda. "Irony, Nostalgia, and the Postmodern." University of Toronto English Library. Ed. Marc Plamondon. 19 Jan 1998. 20 Jan 2006. www.library.utoronto.ca/utel/criticism/hutchinp.html

[4] Prasannarajan, S. Book Review: Weight Loss by Upamanyu Chatterjee. January, 30, 2006.

http://indiatoday.intoday.in/story/book-review-weight-loss-byupamanyu-chatterjee/1/181918.html

[5] "Subjectivism." Wikipedia. 2008. Wikipedia, the free encyclopedia, 25 Sept 2008, http://en.wikipedia.org/wiki/Subjectivism

[6] Singh, R.P. "The Concept of Anti-Hero in the Novels of Upamanyu Chatterje."2010, www.the-criterion.com

[7] Nema, Nidhi. "Exploration of latent irony in explicit grotesquery of upamanyu chatterjee's weight loss," IJELR, vol.3, no. 2, 2016.

[8] Eliot, T.S. "The Waste Land." Liveright Publishing Corporation, 1922.

[9] M. John, "Paradise Lost." Publisher: Samuel Simmons, 1667. 